\title{
FREE PROLINE ACCUMULATION IN SUGARCANE UNDER WATER RESTRICTIONAND SPITTLEBUG INFESTATION
}

\author{
Eduardo Rossini Guimarães ${ }^{1}$; Miguel Angelo Mutton ${ }^{1}$; Márcia Justino Rossini Mutton²*; Maria \\ Inês Tiraboschi Ferro ${ }^{3}$; Gisele Cristina Ravaneli ${ }^{3}$; Jorge Alberto da Silva ${ }^{4}$ \\ ${ }^{1}$ GATEC - Gestão Agroindustrial S/A, Av. Limeira, 222 - $1^{\circ}$ andar - 13414-018 - Piracicaba, SP - Brasil. \\ ${ }^{2}$ UNESP/FCAV - Depto. de Produção Vegetal, Via de Acesso Prof. Paulo Donato Castellane, S/N. 14884-900 - \\ Jaboticabal, SP - Brasil. \\ ${ }^{3}$ UNESP/FCAV - Depto. de Tecnologia. \\ ${ }^{4}$ Texas A\&M University - Agricultural Experiment Station at Weslaco/Soil and Crop Sciences, 2415 East Highway \\ 83 - Weslaco, TX 78596 - USA. \\ *Corresponding author <mjrmut@fcav.unesp.br>
}

\begin{abstract}
Mahanarva fimbriolata (Stål) (Hemiptera: Cercopidae) has become a key pest in the sugarcane (Saccharum officinarum) fields of center-south Brazil. Although some control technologies have shown to be efficient, the damage promoted by this spittlebug species and its interaction with sugarcane are poorly characterized. At high infestation levels the symptoms are similar to those of severe water restriction. This work was conducted to determine whether the stress promoted by spittlebug infestation can be measured in terms of free proline accumulation. The water restriction tolerance of two sugarcane genotypes was also compared. Two experiments were set up in a greenhouse and arranged in a completely randomized design in a $2 \times 2 \times 4$ factorial, with two cultivars (SP80-1816 and RB72454), two stress levels (control and ten nymphs per plant or 50\% water restriction), and four sampling dates. The water deficit caused by spittlebug nymphs sucking xylem sap does not result in proline accumulation, illustrating that there are different mechanisms to sense when the water deficit is caused by insect feeding or water potential variation in root cells. The cultivar RB72454 accumulates more free-proline, and the dry mass accumulation and stalk growth are less affected in this cultivar under water restriction. The levels of compatible solutes probably cannot be used to measure spittlebug infestation stress in sugarcane and RB72454 is more tolerant to water shortage than SP80-1816.
\end{abstract}

Key words: Mahanarva fimbriolata, Saccharum spp., proline accumulation, water deficit

\section{ACÚMULO DE PROLINA EM CANA-DE-AÇÚCAR SOB ESTRESSE HÍDRICO OU SUBMETIDAAOATAQUE DE CIGARRINHA-DAS-RAÍZES}

RESUMO: A cigarrinha-das-raízes Mahanarva fimbriolata (Stål) (Hemiptera: Cercopidae) tornou-se uma praga importante da cultura da cana-de-açúcar na região centro-sul do Brasil. Estratégias de controle têm sido desenvolvidas, mas os danos promovidos por essa praga e sua interação com a cana-de-açúcar ainda são pouco caracterizados. Em altos níveis de infestação da praga, os sintomas nas plantas são muito semelhantes à restrição hídrica severa. Este trabalho foi conduzido com o objetivo de determinar se o estresse promovido pela infestação de ninfas de cigarrinha-das-raízes resulta em acúmulo de prolina livre, além de comparar dois genótipos de cana-de-açúcar quanto à tolerância ao déficit hídrico. Dois experimentos foram conduzidos em delineamento inteiramente casualizado, em esquema fatorial $2 \times 2 \times 4$ com duas cultivares (SP80-1816 e RB72454), dois níveis de estresse (controle e dez ninfas por planta ou 50\% de restrição hídrica) e quatro épocas. O déficit hídrico promovido por $M$. fimbriolata não resultou em acúmulo de prolina, ilustrando a existência de mecanismos distintos para a percepção do estresse hídrico promovido pela praga e pela variação no potencial osmótico nas células das raízes. A cultivar RB72454 acumula maiores teores de prolina livre, e o acúmulo de massa seca e o crescimento dos colmos são menos afetados nessa cultivar sob restrição hídrica. Os teores de solutos compatíveis provavelmente não podem ser utilizados para quantificar o estresse promovido por $M$. fimbriolata em cana-de-açúcar. A cultivar RB72454 é mais tolerante ao déficit hídrico do que a cultivar SP80-1816.

Palavras-chave: Mahanarva fimbriolata, Saccharum spp., acúmulo de prolina, déficit hídrico 


\section{INTRODUCTION}

Harvesting sugarcane with no trash burning has increased year after year in Brazil. The so-called 'green cane' is usually harvested mechanically, leaving a trash layer on soil surface that favors the infestation of some pest and weed species and drastically reduces the occurrence of others, such as photoblastic weed species, for instance.

The spittlebug Mahanarva fimbriolata (Stål) (Hemiptera: Cercopidae) is an example of a pest that has gained more importance with green cane harvesting. Adult females lay their eggs under the trash cover, next to the stalks. When nymphs hatch from eggs, the organic matter layer protects them against drought and sun light exposure (Fewkes, 1969). Nymphs feed mostly on the xylem of young, tender roots (Mendonça \& Mendonça, 2005). Because xylem sap is very poor in amino acids and energy, very large amounts are sucked to provide enough nutrients to these fast-growing insects (Fewkes, 1969).

Dinardo-Miranda (2004); Silva et al. (2005); Garcia et al. (2006) agree that most damage is caused by nymphs rather than leaf-sucking adults. Nymphs are responsible for literally drying stalks and making them hollow, as observed in plants under severe water restriction.

When plants are subjected to water restriction, an increase in the concentration of compatible solutes prevents the loss of water by decreasing the osmotic potential and therefore keeping the water potential at optimal levels. Proline, glycine betaine, sugars and sugar alcohols are examples of compatible solutes involved in osmotic adjustment, providing drought tolerance and guaranteeing plasma membrane integrity without disrupting the protein function (Bray, 1993, 1997; Taiz \& Zeiger, 2004).

Because the symptoms of $M$. fimbriolata infestation and water deficit are similar, it is possible that compatible solutes are accumulated in sugarcane under spittlebug attack. If so, measuring the concentration of such compounds would give an idea of the stress level that would be useful in $M$. fimbriolata resistance studies. The combination of water stress and spittlebug infestation on increasing proline concentration would not be a major concern, because these stresses occur mostly during the winter and late spring/summer, respectively.

This study was undertaken to determine if there is a correlation between $M$. fimbriolata infestation and the accumulation of free proline in sugarcane, and if the level of this amino acid can be used in resistance studies to determine spittlebug tolerance. The drought response of two sugarcane genotypes was also compared in terms of free proline accumulation.

\section{MATERIAL AND METHODS}

No-choice spittlebug and water restriction experiments were carried out in a greenhouse in Jaboticabal, State of São Paulo, Brazil (2114' S; $48^{\circ} 17^{\prime} \mathrm{W}$ ) under controlled temperature and humidity (22 to $33^{\circ} \mathrm{C}$; $\mathrm{RH}=50$ to $60 \%$ ). One-bud seed pieces of the cultivars SP80-1816 (spittlebug-susceptible, Silva et al., 2005; Dinardo-Miranda, 2004) and RB72454 ('less infested' by spittlebugs, DinardoMiranda, 2004; Dinardo-Miranda et al., 1999) were planted in 64-cell Styrofoam trays $(5 \times 10 \mathrm{~cm})$ containing a vermiculite-based substrate.

The water restriction experiment was conducted to verify how spittlebug infestation is correlated to dry soil conditions. Twenty-seven days after planting (DAP), plantlets were transplanted to 15-liter plastic pots (one plantlet per pot) containing fertilized, medium textured soil. Pots were watered daily to field capacity and later to water stress treatments.

The spittlebug experiment was arranged in completely randomized design, in a $2 \times 2 \times 4$ factorial with two sugarcane genotypes, two infestation levels (control and ten nymphs), and four sampling dates (8, 17, 39 and 68 days after inoculation - DAI). The same design was used in the water restriction experiment, and factors represented the two sugarcane genotypes, two water restriction levels (control and 50\% water availability) and four sampling dates (five days before water restriction and 21, 48 and 91 days after). Four replications were used in both experiments. Data were subjected to an ANOVA and means were compared by the Tukey test at $5 \%$ of probability.

\section{Spittlebug rearing and infestation}

To maintain soil humidity and stabilize the temperature for future infestation of spittlebug nymphs, pots were covered with $65 \mathrm{~g}$ of ground and sun-dried tops and leaves, simulating sugarcane trash $(70-80 \%$ of dry mass, corresponding to 9 tons ha ${ }^{-1}$ ), 17 days before inoculation. Spittlebug nymphs were reared as described by Garcia et al. (2006), to perform an infestation with 21-day-old nymphs at 94 DAP using a soft brush, at rates of 0 (control) and 10 nymphs per plant. Spittlebug foam was transferred abundantly with nymphs to guarantee survival after infestation. Covering pots with a 100-mesh nylon net right after inoculation isolated the effect of leaf-sucking adults and avoided nymph migration (no-choice test). Pots were monitored daily and all adults found were immediately killed. The presence of adults was avoided not to have new ovipositions that would result in undesired variation. Also, according to Dinardo-Miranda (2004) most of the damage is caused by nymph feeding. 


\section{Water restriction}

Plants were watered daily to field capacity until 94 DAP to allow adequate initial growth. An atmometer was used to estimate to amount of evapotranspiration and $50 \%$ water restriction was applied by watering half of the evapotranspiration of the previous day (Broner \& Law, 1991).

\section{Free proline quantification}

Sugarcane leaves $(+1$, Küijper system) were collected 8, 17, 39 and 68 days after spittlebug inoculation (DAI) and five days before water restriction, and 21, 48 and 91 days after. Leaves were ground in liquid nitrogen to enhance proline extraction. The levels of free proline were measured as described by Bates et al. (1973). Results were expressed in ìmols of proline per gram of leaf fresh mass, as follows: [ $(\mu \mathrm{g}$ proline $\left.\left.\mathrm{mL}^{-1} \times 4 \mathrm{~mL}^{* *}\right) / 115.5 \mu \mathrm{g} \mu \mathrm{mol}^{-1}\right] /[(\mathrm{g}$ sample $) / 5]$ **toluene volume.

\section{Dry mass, stalk height and diameter analyses}

The dry mass accumulation, stalk height and diameter were measured to determine if the stress treatments were effective in slowing sugarcane development. Stalk height was measured from the soil to the first visible auricle with the help of a ruler, while diameter was determined with an external micrometer at the middle portion of the stalk. At the end, plants were dissected into leaves, stems and roots, and dried in a forced-air oven at $70^{\circ} \mathrm{C}$ to constant mass. Dry mass was determined in a milligram electronic balance. To remove soil particles, roots were washed in water flow and dried with paper towel. After weighing, samples were placed in paper bags.

\section{RESULTS AND DISCUSSION}

The dry mass of stalks, leaves and roots was affected ( $p \leq 0.01)$ by spittlebug nymph feeding on varieties SP80-1816 and RB72454. Nymph mortality was lower than $20 \%$ and no difference was observed between cultivars, indicating that both are susceptible

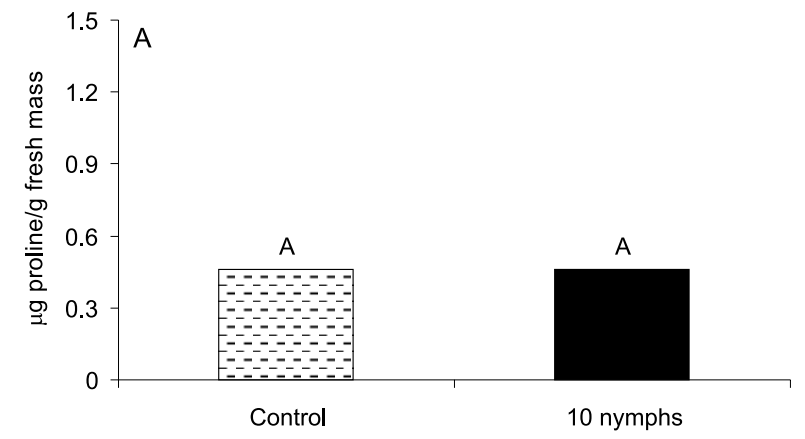

to M. fimbriolata (Guimarães et al., 2007). Spittlebug infestation did not result in free proline accumulation in sugarcane leaf tissues and no difference was detected between cultivars or sampling dates in the spittlebug experiment (Figure 1, Figure 2A).

Streck (2004) discussed the mechanisms by which plants sense drought and showed that the strongest candidates are hydraulic signals in shoots and molecular signaling from roots, but there is still much contradiction and details of water shortage sensing mechanisms remain unclear. The fact that the 'drought symptom' caused by xylem-sucking spittlebug nymphs does not result in proline accumulation shows that there are different mechanisms to sense when the water deficit is caused by insect feeding or water potential variation in root cells. Spittlebug nymph feeding is responsible for water shortage in leaves and results in hydraulic signals that stimulate stomatal closure. So it is likely that hydraulic signals themselves are not responsible for compatible solute accumulation. On the other hand, the free proline accumulation in plants subjected to water restriction (Figure 2A) illustrates that the chemical signals from roots are involved in osmotic adjustment.

At an ideal water status the xylem sap $\mathrm{pH}$ is lower while at water shortage it is higher. When the sap is more basic, the abscisic acid (ABA) becomes deprotonated and does not pass the membrane of mesophyll cells, so it is accumulated in guard cells, inducing stomatal closure (Taiz \& Zeiger, 2004). Since both spittlebug infestation and drying soil are expected to promote stomatal closure, our results indicate that the molecular signaling from roots plays an important role in distinguishing when the water deficit is caused by drying soil or sap-sucking insects (Figure 2A).

The sugarcane cultivar RB72454 accumulates more free-proline (Figure 2), and the dry mass accumulation, stalk height and diameter are less affected by water restriction for this cultivar (Figures 3 and 4). These results are an indication that this cultivar is more tolerant to drought conditions than SP80-1816.

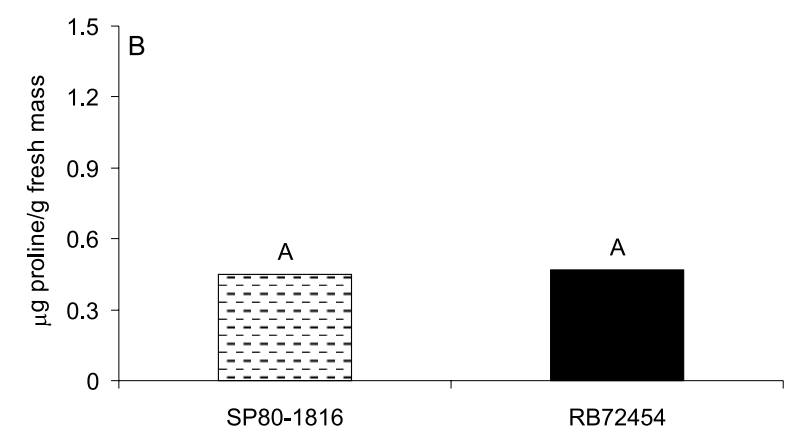

Figure 1 - Levels of free proline in the spittlebug experiment. Different letters indicate difference at 5\% (Tukey test). A - Effect of infestation; B - Effect of sugarcane cultivars. 

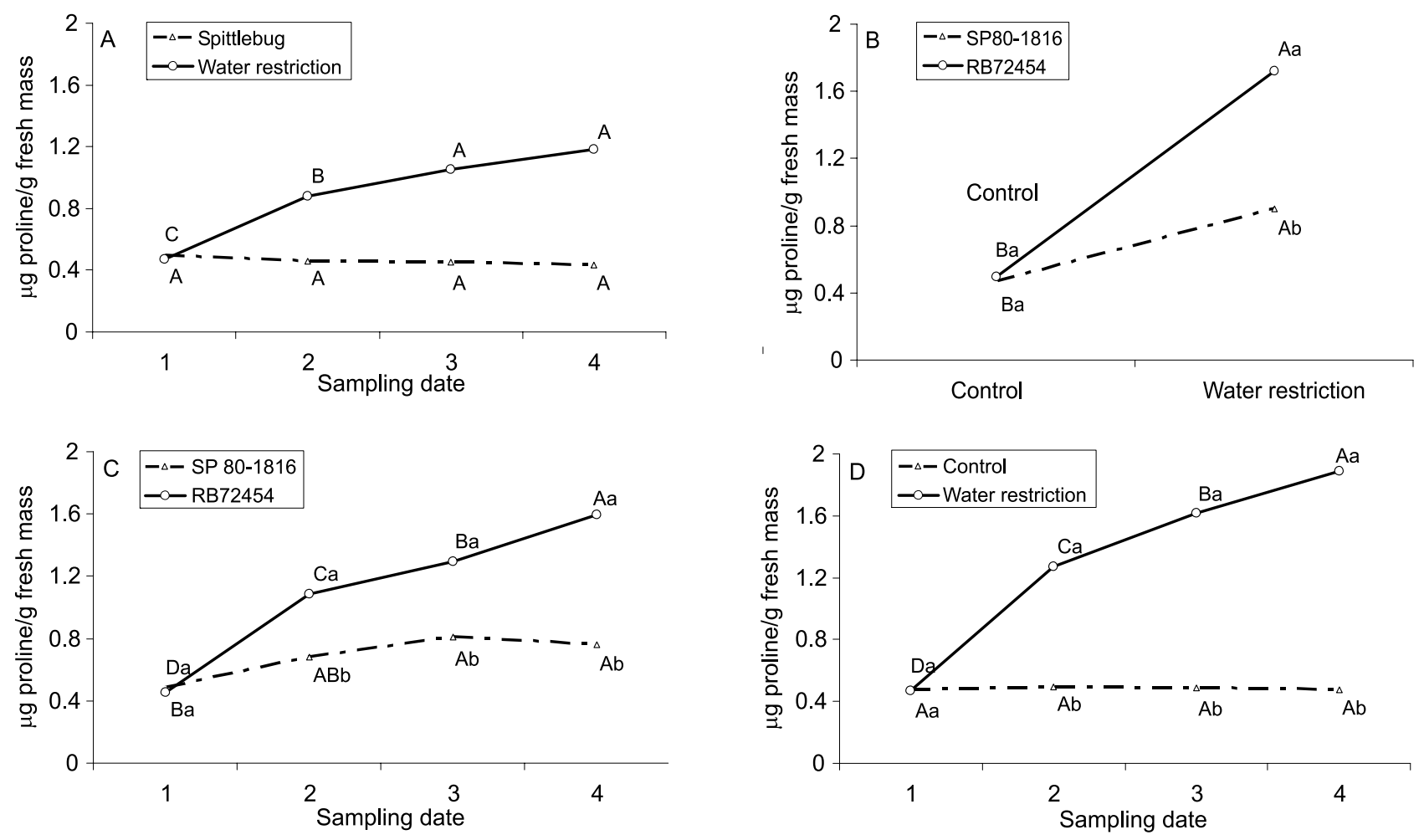

Figure 2 - Levels of free proline (water restriction experiment). A - Comparison of spittlebug infestation and water restriction over the sampling dates; B - Effect of sugarcane cultivars; C - Cultivars over time; D - Effect of water restriction over time. Capital letters compare means within treatments and lower-case letters compare means between treatments.
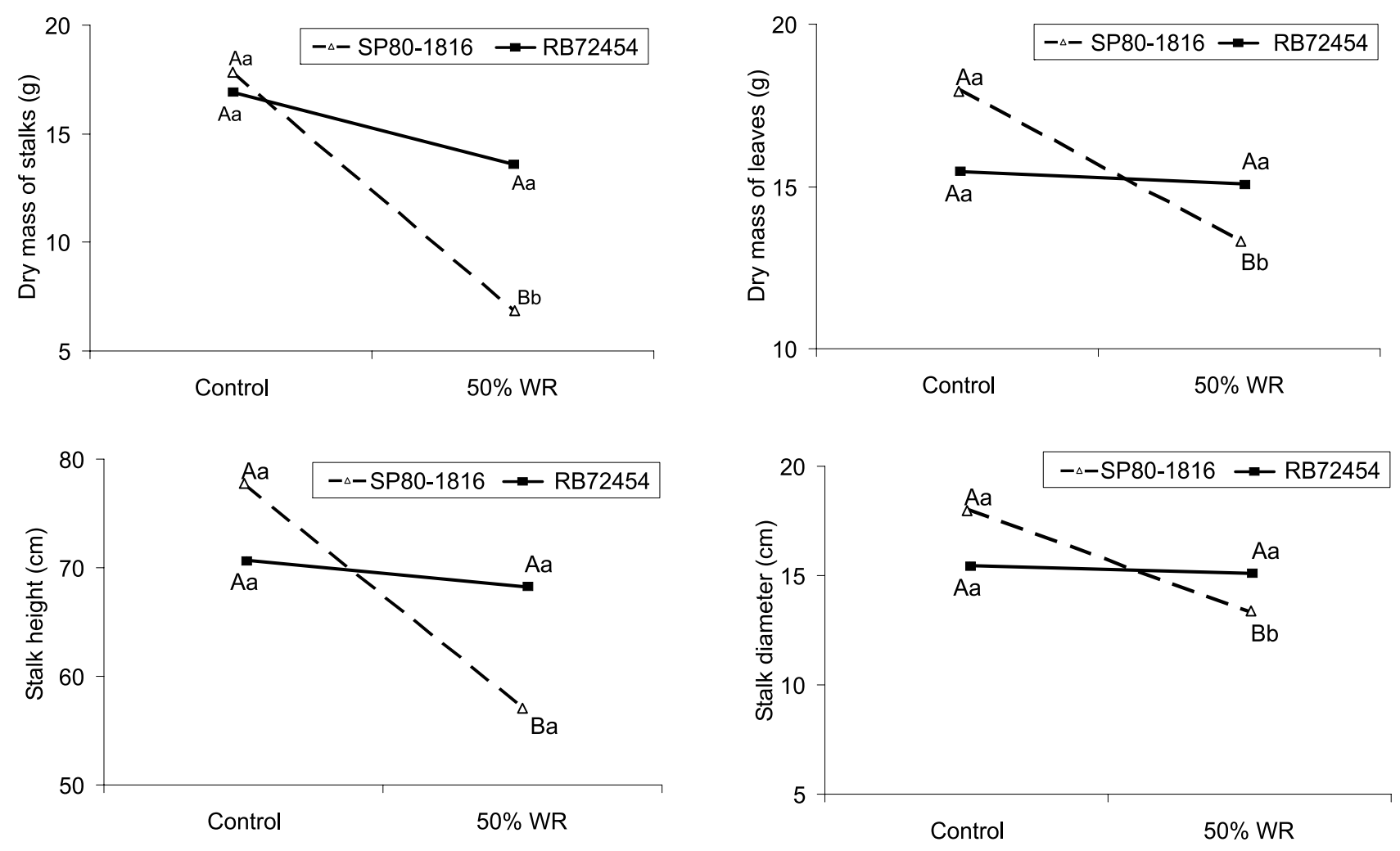

Figure 3 - Dry mass accumulation, stalk height and diameter in the water restriction experiment. Capital letters compare means within treatments and lower-case letters compare means between treatments. WR = Water restriction. 


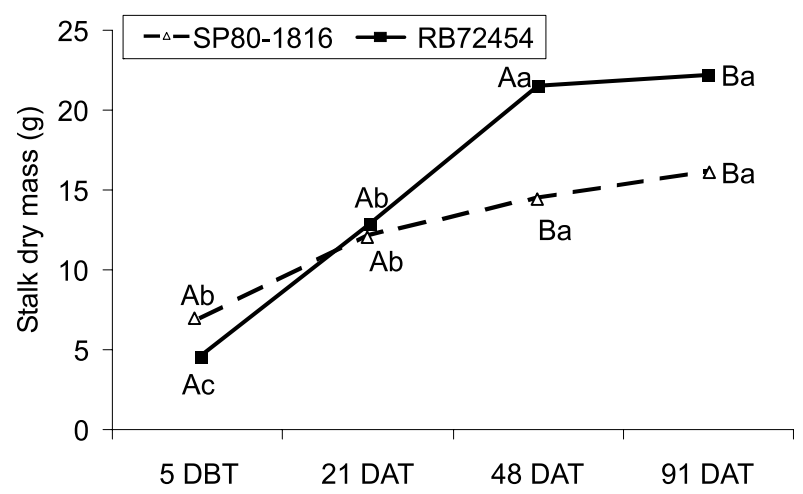

Figure 4 - Comparison of sugarcane cultivars over time (water restriction experiment). DBT - Days before water restriction treatment; DAT - Days after water restriction treatment. Capital letters compare means within treatments and lower-case letters compare means between treatments.

One of the most studied plant responses to water deficit is the accumulation of free-proline, and many reports show a strong correlation between proline accumulation and drought tolerance increase, e.g. Nepomuceno et al., 2001 and Marin et al., 2006. Many other roles that indirectly help plants tolerate water shortage have been suggested for proline accumulation, like stabilizing sub-cellular structures, free-radical scavenging, energy storage and stress molecular signaling (Bartels \& Sunkar, 2005).

Proline is synthesized from glutamate and pyrroline-5-carboxylate (P5C) through successive reductions catalyzed by pyrroline-5-carboxylate synthase (P5CS) and pyrroline-5-carboxylate reductase (P5CR). It can also be produced from ornithine by ornithine d-aminotransferase (OAT). Proline accumulation also depends on its catabolism by proline dehydrogenase (ProDH), and P5C dehydrogenase (P5CDH) (Hare et al., 1999). Under water restriction, proline seems to be synthesized mostly from the glutamate pathway (Bartels \& Sunkar, 2005).

The expression of reductase (P5CR) is regulated by osmotic potential variation in the cytoplasm (Williamson \& Slocum, 1992). An osmotic potential decrease induces the P5C biosynthesis, which results in proline synthesis. The accumulation of free proline in plant cells subjected to water restriction has been attributed to an osmotic adjustment mechanism (Delauney \& Verma, 1993).

Both spittlebug infestation and water restriction reduced dry mass accumulation and stalk growth, and the general appearance of plants subjected to these stresses were quite similar. However, the accumulation of free-proline was not affected by spittlebug infestation, probably because an osmotic potential variation is necessary for P5C biosynthesis. Spittlebug nymphs feed directly on xylem (and partly phloem) sap (Fewkes, 1969; Mendonça \& Mendonça, 2005), which is not expected to cause any osmotic potential alteration in root cells. Although compatible solutes act synergistically in promoting osmotic stress tolerance, free proline is one of the most effective and quickly accumulated substance. Therefore, it is likely that other compatible solutes cannot be used to measure the stress caused by $M$. fimbriolata.

The water deficit caused by xylem-sucking spittlebug nymphs does not result in proline accumulation, illustrating there are different mechanisms to sense when the water deficit is caused by insect feeding and water potential variation in root cells. This is an indication that the level of compatible solutes probably cannot be used to measure the stress caused by $M$. fimbriolata. Both spittlebug infestation and water restriction reduce dry mass accumulation and stalk growth, causing similar symptoms.

The cultivar RB72454 accumulates more freeproline and its growth is less affected by water restriction than SP80-1816, which suggests that the former is more tolerant to water restriction.

\section{REFERENCES}

BARTELS, D.; SUNKAR, R. Drought and salt tolerance in plants. Critical Reviews in Plant Sciences, v.24, p.23-58, 2005.

BATES, L.S.; WALDREN, R.P.; TEARE, I.D. Rapid determination of free proline for water stress studies. Plant and Soil, v.39, p.205-207, 1973.

BRAY, E.A. Molecular responses to water deficit. Plant Physiology, v.103, p.1035-1040,1993.

BRAY, E.A. Plant responses to water deficit. Trends in Plant Science, v.2, p.48-54, 1997.

BRONER, I.; LAW, R.A.P. Evaluation of a modified atmometer for estimating reference ET. Irrigation Science, v.12, p.216, 1991.

DELAUNEY, A.; VERMA, D. Proline biosynthesis and osmoregulation in plants. Plant Journal, v.4, p.215-223, 1993.

DINARDO-MIRANDA, L.L.; FIGUEIREDO, P.; LANDELL, M.G.A.; FERREIRA, J.M.G.; CARVALHO, P.A.M. Danos causados pelas cigarrinhas-das-raízes (Mahanarva fimbriolata) a diversos genótipos de cana-de-açúcar. STAB: Açúcar, Álcool e Subprodutos, v.17, p.48-52, 1999.

DINARDO-MIRANDA, L.L. Cigarrinha-das-raízes em cana-deaçúcar. In: SALVADORI, J.R.; ÁVILA, C.J.; SILVA, M.T.B. (Ed.) Pragas de solo no Brasil. Passo Fundo: Embrapa, 2004. p.495-516.

FEWKES, D.W. The biology of sugar cane froghoppers. In: WILLIAMS, J.R.; METCALFE, J.R.; MUNGOMERY, R.W.; MATHES, R. (Ed.) Pests of sugar cane. Amsterdam: Elsevier, 1969. p.281-307.

GARCIA, J.F.; BOTELHO, P.S.M.; PARRA, J.R.P. Biology and fertility life table of Mahanarva fimbriolata (Stål) (Hemiptera: Cercopidae) in sugarcane. Scientia Agricola, v.63, p. 2006.

GUIMARÃES, E.R.; MUTTON, M.A.; FERRO, M.I.T.; SILVA, J.A.; MUTTON, M.J.R.; KALAKI, D.B.; MADALENO, L.L. Evidence of sugarcane resistance against Mahanarva fimbriolata (Stål, 1854) (Hemiptera: Cercopidae). In: ISSCT CONGRESS, 26., Durban, 2007. Proceedings. Durban: D.M. Hogarth, 2007. p.123. 
HARE, P.; CRESS, W.; STADEN, J. van. Proline synthesis and degradation: a model system for elucidating stress-related signal transduction. Journal of Experimental Botany, v.50, p.413434, 1999.

MARIN, A.; SANTOS, D.M.M.; BANZATTO, D.A.; CODOGNOTTO, L.M. Influência da disponibilidade hídrica e acidez do solo nos teores de prolina livre de guandu. Pesquisa Agropecuária Brasileira, v.41, p.355-358, 2006.

MENDONÇA, A.F.; MENDONÇA, I.C.B.R. Cigarrinha da raiz Mahanarva fimbriolata (Hemiptera: Cercopidae). In: MENDONÇA, A.F. (Ed.) Cigarrinhas da cana-de-açúcar: controle biológico. Maceió: Insecta, 2005. cap.3, p.95-200.

NEPOMUCENO, A.L.; NEUMAIER, N.; FARIAS, J.R.B.; OYA, T. Tolerância à seca em plantas: mecanismos fisiológicos e moleculares. Biotecnologia Ciência \& Desenvolvimento, n.23, p.12-18, 2001.
SILVA, R.J.N., GUIMARÃES, E.R., GARCIA, J.F.; BOTELHO, P.S.M.; FERRO, M.I.T.; MUTTON, M.A.; MUTTON, M.J.R. Infestation of froghopper nymphs changes the amounts of total phenolics in sugarcane. Scientia Agricola, v.62, p.543-546, 2005.

STRECK, N.A. Do we know how plants sense a drying soil? Ciência Rural, v.34, p.581-584 2004.

TAIZ, L.; ZEIGER, E. Fisiologia vegetal. Porto Alegre: Artmed, 2004, 719p.

WILLIAMSON, C.L.; SLOCUM, R.D. Molecular cloning and evidence for osmoregulation of the 1-pyrroline-5-carboxylate reductase (proC) gene in Pea (Pisum sativum L.). Plant Physiology, v.100, p.1464-1470, 1992.

Received March 13, 2007

Accepted April 03, 2008 